\begin{tabular}{|c|c|c|}
\hline \multirow{3}{*}{$\begin{array}{l}\text { EREM 73/2 } \\
\text { Journal of Environmental Research, } \\
\text { Engineering and Management } \\
\text { Vol. } 73 \text { / No. } 2 \text { / } 2017 \\
\text { pp. } 7-20 \\
\text { DOl 10.5755/j01.erem.73.2.13399 } \\
\text { @ Kaunas University of Technology }\end{array}$} & \multicolumn{2}{|c|}{$\begin{array}{c}\text { Indicators of Sustainable Development for Health Care } \\
\text { Waste Treatment Industry }\end{array}$} \\
\hline & Received 2015/10 & Accepted after revision 2017/07 \\
\hline & \multicolumn{2}{|c|}{ Crossef http://dx.doi.org/10.5755/j01.erem.73.2.13399 } \\
\hline
\end{tabular}

\title{
Indicators of Sustainable
}

\section{Development for Health Care Waste Treatment Industry}

\section{Olivia Maamari}

Saint Joseph University of Beirut, Faculty of sciences, Chemistry department, B.P. 11-514, 11072050, Beirut, Lebanon "arcenciel", environment program, B.P. 165216, Beirut, Lebanon

Unité de Recherche Environnement, Génomique Fonctionnelle et Études Mathématiques (UR-EGFEM)

\section{Jounaid Maurice}

"arcenciel", environment program, B.P. 165216, Beirut, Lebanon

\section{Cedric Brandam}

Ecole Nationale Supérieure des Ingénieurs en Arts Chimiques Et Technologiques, Toulouse, France Laboratoire de Génie Chimique, Toulouse, France

\section{Roger Lteif}

Saint Joseph University of Beirut, Faculty of sciences, Chemistry department, B.P. 11-514, 11072050, Beirut, Lebanon Saint Joseph University of Beirut, Technology Health Pole, Beirut, Lebanon

Unité de Recherche Environnement, Génomique Fonctionnelle et Études Mathématiques (UR-EGFEM)

\section{Dominique Salameh}

Saint Joseph University of Beirut, Faculty of sciences, Chemistry department, B.P. 11-514, 11072050, Beirut, Lebanon Unité de Recherche Environnement, Génomique Fonctionnelle et Études Mathématiques (UR-EGFEM)

Corresponding author: oliviam@arcenciel.org

Olivia Maamari, Saint Joseph University of Beirut, Faculty of sciences, Chemistry department, B.P. 11-514, 11072050, Beirut, Lebanon 
Sustainable development is more and more considered as a key parameter and a driving strategy for sustainable performance. Today, numerous organizations develop their own performance indicators as no standard set of performance indicators could be generalized as meaningful in terms of sustainability performance. Particularly, the context of developing countries, where the concept of sustainability is not well diffused yet and where economic difficulties and constraints result most of the times in underestimation of environmental and social considerations, requires specifically adapted indicators. Specially, the sector of health care waste management lacks of sustainability indicators. This sector ensures the treatment, before disposal, of hazardous health care waste generated by health care centers (hospitals, clinics, and others). The evaluation system is designed for monitoring the pace of gaining sustainability within this sector. The objective of this article is to propose a sustainability evaluation system adapted to the needs and situation of developing countries, based on meaningful, practical, easily measurable and applicable indicators for the Infectious Health Care Waste (IHCW) Treatment sector.

Keywords: Infectious Health Care Waste Treatment Industry, sustainability, indicators, sustainable performance.

\section{Introduction}

Contemporary economic and social development patterns are exerting increasing pressure on natural resources. This situation is threatening collective sustainability of human society (GRI 2006), (EPA 2012). Sustainable development is defined as the development, which meets the needs of the present without compromising the ability of future generations to meet their own needs (WCED 1987). Sustainable development at an organizational level consists in measuring performance through evaluating it through its economic, environmental and social components (GRI 2006), (Staniškis and Arbačiauskas 2009), (Harmsen and Powell 2010), (EPA 2012). Sustainable development is more and more considered as a key parameter and a driving strategy for sustainable performance (Staniškis and Arbačiauskas 2009), (Van Passelet et al. 2009), (Harmsen and Powell 2010), (Fortuna 2011). Performance indicators are the main efficient tool used to evaluate and monitor sustainability performance, and give useful information to describe the situation and to indentify optimization opportunities (Warhurst 2002), (Cobb et al. 2007), (Staniškis and Arbačiauskas 2009), (Harmsen and Powell 2010), (Yazdi 2014).

During the past year, considerable efforts, mainly motivated by the society increasing demand for information and accountability, were accomplished into the development of sustainable development indicators (Warhurst 2002), (EPA 2012). Different initiatives came from the UN, OECD, European Union, governments, NGOs, the academic and business sectors (Warhurst 2002). The main existing tools for the evaluation of sustainability include the "Core Set of Environmental Performance Reviews" (OECD 1993, 1994) aiming to improve nations' environmental performances; the Global Reporting Initiative (GRI 1997), providing guidelines for sustainability reporting; International Standards ISO 26000:2010, providing guidance on social responsibility practices; the World Business Council for Sustainable Development (WBCSD) methodology for eco-efficiency assessment (2007); and international standard ISO 14001:2004 for environmental performance evaluation (Warhurst 2002), (Staniškis and Arbačiauskas 2009), (EPA 2012).

The French IDEA method (Indicateurs de Durabilité des Exploitations Agricoles - Farm Sustainability Indicators) translates the concept of farm sustainability into a system of indicators. This method is designed as a self-assessment grid, and includes 41 indicators covering the three dimensions of sustainability in agriculture (agroecological, socio-territorial and economic) (Zahm 2005). The Institute for Sustainability of the American Institute of Chemical Engineers (AIChE) developed the AIChe index in 2007 for the quantification of sustainability efforts in the chemical industry (Cobb et al. 2007). The index includes the following categories: strategic commitment to sustainability, safety performance, environmental performance, social responsibility, product stewardship, innovation, and value chain management (Cobb et al. 2007). 
The Mining and Energy Research Network (MERN) has conducted research on the development of Sustainability Performance Indicators and management systems for the mining, metals and energy sectors (Warhurst 2002).

Nevertheless, selection and application of sustainability performance indicators are not yet mastered very well and still being explored (Staniškis and Arbačiauskas 2009). Given the complexity of the definition of sustainable development concept, there is no uniform consensus on indicators (Sikdar 2007). This situation has given rise to a profusion of indicators, metrics, and tools (Wilson et al. 2007), (Harmsen and Powell 2010).

In general, the main weakness of existing sustainability evaluation systems is their focus on external reporting, rather than on the internal needs for decision-making, and sustainability effectiveness improvement (Warhurst 2002), (Staniškis and Arbačiauskas 2009). Besides, the sustainability indicators foreseen in the ISO series can be difficult to measure, have high cost for the measurement of some indicators, and are not practicable to use for a great part of the world companies (Raiser Neto et al. 2006).

Today, numerous organizations develop their own performance indicators. In fact, no standard set of performance indicators could be generalized as meaningful in terms of sustainability performance. Organizations have to develop their own sets of indicators corresponding to their specific needs, mission, and activities (Azapagic and Perdan 2000), (Warhurst 2002); (Staniškis and Arbačiauskas 2009). Tailor made approaches developed within the company are more expected to support learning and to implement adapted and flexible methodologies (Warhurst 2002).

Particularly, the context of developing countries, where the concept of sustainability is not well diffused yet and where economic difficulties and constraints result most of the times in underestimation of environmental and social considerations, requires specifically adapted indicators. It is crucial that decision-makers address today sustainability issue, even imperfectly, as ignoring it may only aggravate the problem (Azapagic and Perdan 2000).

The most important criteria that define an indicator are the capacity to simplify, quantify, analyze and communicate information (Warhurst 2002). In order to be valuable and useful, the key requirements for indicators that should be fulfilled are comparability/ measurability, meaningfulness, integrity, continuity, clarity and efficiency (Staniškis and Arbačiauskas 2009), (EPA 2012). Indicators should evaluate performance regarding two main areas: the extent of which a product, service or activity is contributing to life quality and health; and the extent to which a project is being managed according to sustainable development practices (Warhurst 2002). The best approach is the combination of quantitative and qualitative indicators (Staniškis and Arbačiauskas 2009). Ensuring that sufficient high quality data is collected, and designing reliable methodologies for processing data into indicators are essential in designing performance indicators (Warhurst 2002).

Health-care waste (HCW) includes all the waste generated by health-care establishments, research facilities, and laboratories (WHO; 2013). In average $10-25 \%$ of HCW is Health-care risk waste (HCRW) that requires special treatment due to the risks that it poses both to human health and the environment (WHO; 2013). HCRW management is a high-priority environmental concern because poor management of this type of waste causes health problems due to the proliferation of micro-organisms as well as environmental problems due to the contamination of ground water by untreated health care waste (Dursun; 2011). Infectious Health Care Waste (IHCW) forms the larger fraction of HCRW and should be treated by sterilization before joining the non hazardous waste stream for final disposal, in landfills or others. IHCW treatment is very important for preventing pollution and spread of diseases. IHCW treatment technologies include autoclaves; integrated steam-based treatment systems; microwave treatment technologies; dry-heat treatment technologies; chemical treatment technologies; and incinerators (WHO, 2013). The mission of the Health Care Waste Treatment sector is to provide the proper sterilization of IHCW before final disposal. Therefore, the IHCW treatment sector has a significant positive impact on health and environment. However, as any industry, IHCW treatment sector could also have a negative impact (consumption of energy, generation of wastewaters, operator's exposure to 
risks, etc.) that should be evaluated and monitored. To the best knowledge of the authors, no indicators systems capable of evaluating sustainability performance have been developed for the health care waste treatment sector that falls under the hazardous solid waste management industry. In fact, it is evident that sustainability is of the essence of the waste treatment activity since environment preservation, public health protection and social integration are the main objectives of this action. However, the choice of the treatment techniques, the level of cost-efficiency and optimization of the process, of the safety and of the effectiveness, as human resources management methods, can change the way this service can impact earth, persons, and economies (GRI 2006).

Few Lebanese health care institutions treated their IHCRW before disposal until 2003. In response to this critical problem, the NGO "arcenciel", in collaboration with the Faculty of Science of St Joseph University, developed a national network that ensures the appropriate collection and treatment of IHCW in 5 waste management facilities, covering all the country. The treatment technique is the steam sterilization associated with shredding/fragmentation. This network provides the treatment of more than $80 \%$ of IHCW in Lebanon and covers 256 health care centers. The network is a self-regulated system ensuring a triple control: The services of "arcenciel", as a treatment operator, are monitored by health care institutions because waste producers are responsible for the waste they generate until final disposal, according to the "polluter pays principle" included in the Lebanese law 444; 2002. "arcenciel" monitors IHCW quantities and reports them to the Ministry of the Environment. As required by the Lebanese decree 13389; 2004, the Ministry of the Environment monitors the whole system and "arcenciel" facilities through environmental impact assessments, audits, and regular reports (Maamari et al., 2015a). Thus, the main stakeholders involved in the Health Care Waste Management sector in Lebanon include the Ministry of Environment (monitoring entity), the health care centers (IHCW producers and operator's clients), the academic and scientific sector (that contributes in establishing standards and procedures) and the IHCW collection and treatment operators (mainly "arcenciel" for the time being, that implements standards and procedures). Knowing that according to the "polluter pays principle", hospitals should bear the costs of their IHCW management, and should therefore pay the service provider for the treatment of their $\mathrm{HCW}$, variable pricing (price per kilogram) was adopted in order to provide incentives for the proper segregation and reduction of IHCW, and thus cost saving. In Lebanon, IHCW collection and treatment average fees is $0.64 \mathrm{USD} / \mathrm{kg}$, for the service provided by "arcenciel". Considering the weighted mean of $1.14 \mathrm{~kg}$ bed-1 day-1, and knowing that there are 15,342 hospitals beds (164 hospitals) in Lebanon, we can estimate that the total IHCW generated in Lebanon is equal to $6,383,806 \mathrm{~kg} /$ year (Maamari et al., 2015, b). Considering a total population in Lebanon of 4,425 million (World Bank, 2012), we can estimate an IHCW generation of $1.42 \mathrm{~kg} /$ capita/year (Maamari et al., 2015b). The IHCW sector in Lebanon employs more than 50 persons. The majority of these persons are low-qualified or in social reinsertion (ex-prisoners, ex-drugs addicts, etc.) (Maamari et al., 2015a).

After more than many years of research and experience in the field of Infectious Health Care Waste Treatment, different needs were identified in terms of sustainability in this sector, notably in developing countries where sustainable development is often neglected: 1) the need of strategic commitment to enhance efforts and engagement towards sustainability within this sector; 2) the need of increasing environmental performance to ensure that environmental safe technologies and processes are adopted and that the use of not well controlled incineration technologies is avoided, notably to reduce the risk of emissions of dioxins; 3 ) the need of more social responsibility, to ensure that human resources are working in good conditions, and to ensure that this sector of activity that creates low-qualified jobs, is used as an opportunity for the integration of marginalized persons; 4) the need of enhancing safety performance, since this sector deals with hazardous waste and industrial heat technologies, and to ensure that human resources are properly protected from increased exposure to infectious health care waste and other occupational hazards, and; 5) the need of ensuring that the service provided is economically viable, affordable for beneficiaries and that adopted processes are cost efficient. 
Thus, a monitoring system for sustainability should be developed for this sector of activity, taking into consideration the following key aspects: strategic commitment, environmental performance; social responsibility, safety performance, and economical performance.

The objective of this article is to fill in the gap of a monitoring system for HCW treatment sector through proposing to stakeholders involved in the health care waste management industry, a sustainability evaluation system adapted to the needs and situation of this sector in developing countries. This evaluation system, developed by the scientific sector in collaboration with an IHCW treatment operator, would be facilitating the monitoring of sustainability within this sector, and would be very helpful in fostering collaborative links between the main actors which are Government, businesses and scientific communities. Thus, this study foresees intersectoral cooperation between Universities (Saint Joseph University), Waste Treatment organizations (arcenciel), and governmental institution (the Ministry of Environment) that falls into the Triple Helix model, suggested by Etzkowitz, (1997, 2004, 2008).

\section{Materials and Methods}

As a first step, the main problem and scope of action were defined. The addressed problematic was to develop tools for the assessment, the development and the maintenance of the sustainability performance of health care waste treatment sector, in order to mitigate potential negative impacts and to enhance positive ones, while ensuring the durability and viability of this public interest service and its availability for the community. Three dimensions could be taken into consideration into sustainable development: the social dimension (taking into consideration the most vulnerable target groups while conducting an action); the environmental dimension (preserving natural resources); and the economical dimension (bringing autonomy through financial independence).

The second step was the identification and selection of adequate indicators, allowing evaluating the three sustainable development dimensions in the health care waste treatment activity. First, a review was conducted on the main sustainability methodologies and indicators available in the literature. As mentioned in the introduction, the systems considered in this study are proposed by the UN, OECD, European Union, governments, NGOs, the academic and business sectors. Based on a deep review of these methodologies and indicators (reported in the references), the most meaningful, practical, easily measurable and applicable indicators for the Health Care Waste Treatment sector were selected. Afterwards, selected indicators were adapted, simplified and clarified in a way to allow a monitoring of the changes over time, and facilitate the identification of problems and opportunities, and the decision making process. The simplicity of the indicators was a key requirement in order to ease the comprehension and the application of the indicators and promote their utilization. Proposed indicators were regrouped according to the following taxonomy covering the main identified needs described in the introduction, and the different aspects of sustainability: strategic commitment, environmental performance, social responsibility, safety performance, and economical performance.

The third step consisted in data collection. Care was taken to ensure information reliability.

This work was done by the Faculty of Sciences of Saint Joseph University and "arcenciel", a Lebanese 30 year NGO, recognized of public utility. "arcenciel"'s mission is to participate in the sustainable development of society by supporting fragile groups and integrating marginalized persons. The objective of the organization revolves around sustainable development, by taking into account the persons and groups that are most vulnerable; preserving natural resources and the environment; and ensuring maximum economic and financial autonomy. The association created a national network for health care waste management in 2003, and is operating it until now. This NGO, which works like a social enterprise, is a pioneer in the field of sustainable development in Lebanon, and is the major national actor of the Health Care Waste treatment sector. Therefore, the input and feedback of this NGO can be considered as reliable, and relevant for the objectives of the study.

An index of indicators, specific for health care waste treatment industries in developing countries, was 
developed. A total of 45 quantitative and qualitative indicators, regrouped in 5 main categories, were selected. The categories are the following: strategic commitment (5 indicators), environmental performance (9 indicators); social responsibility (12 indicators), safety performance (12 indicators), and economical performance (7 indicators) i.e. $11.11 \%$ for strategic commitment; $20.00 \%$ for environmental performance; $26.67 \%$ for social responsibility; $26.67 \%$ for safety performance; and $15.56 \%$ for economical performance. These percentages are representative of the relative level of importance of each category for the health care waste treatment activity. Each indicator is rated depending of the level of sustainability: 0 for low sustainability, 1 for medium sustainability, and 2 for high sustainability. For each indicator, description references allow to determinate the level of sustainability of the evaluated activity (tables 1, 2, 3, 4, and 5). The percentage of sustainability of each category of indicator was calculated using the following formula:

Percentage of sustainability

$$
\begin{aligned}
& =\frac{\text { Sobtained scores }}{(\text { total number of indicators in the category } * \text { maximal score for each indicator })} \\
& * 100
\end{aligned}
$$

In order to reduce the evaluation subjectivity related to qualitative indicators, and since quantitative indicators references values cannot be generalized to all contexts, indicators are linked to a quantitative type of indicator, when applicable. Thus, after conducting a first step of evaluation to define low and medium sustainably areas, areas of efforts could be defined and limited number of Key Performance Indicators (KPI) (business metric used to evaluate factors that are crucial to the success of an organization), focusing on the main areas where progress should be done, could be selected from the 45 indicators proposed. Then, proposed methods of indicators quantification would help in measuring and following progress from one year to another.

\section{Results and discussion}

The selected indicators, relevant to the 5 areas of strategic commitment, environmental performance, social responsibility, safety performance, and economical performance are presented in the 5 tables (table 1, table 2, table 3, table 4, table 5).

The sustainability evaluation results for the Health Care Waste Treatment Sector in Lebanon showed in the figure 1 illustrate the level of integration of the different aspects of sustainable development in the sector. For instance, the environmental performance and the economic performance are relatively low, whereas the social responsibility performance is relatively high. These results are foreseeable since in Lebanon the main operator of this sector is an NGO, whose mission is to participate in the sustainable development of society by supporting fragile groups and integrating marginalized persons, and since it is a Non-for Profit organization. Nevertheless, these results indicate that more efforts should be made to increase economic independence and capacity of self-financing, and more investment should be done, when possible, to increase environmental performance of the process. Thus, Key Performance Indicators related to these aspects should be selected and efforts should be concentrated on these areas of interventions, in order to enhance sustainability within the sector.

In some cases, some negative correlation can occur between indicators or areas of interventions. For instance, even if as reported by Warhurst (2002), previous studies show a positive correlation between environmental performance and economic performance, the cost of the measures for improving environmental performance (replacement of heavy fuel by light clean fuel for instance) can negatively impact economic indicators. This is notably the case if the cost is not passed to the consumer, or if the measure does not allow reducing costs related to generated pollution. In fact, in developing countries, polluter pays principle, 
or pollution related taxes or penalties are rarely implemented. Thus, environmental performance represents a supplemental cost that organizations are not obliged to pay.

Besides, in the case of waste treatment activities, hospitals in developing counties are already reluctant to pay for the service of waste treatment, especially when the application of legislation is not enforced. Therefore, additional costs related to environmental performance increasing measures cannot be reported to the price paid by consumers and should be incurred by the organization ensuring the service. Other examples of negative correlation can occur: for instance, using thinner bags allows reducing environmental impact but also reduces safety performance. In these cases, organizations should achieve compromise if possible without threatening safety.

\section{Table 1}

Strategic Commitment evaluation grid

\begin{tabular}{|c|c|c|c|c|c|}
\hline 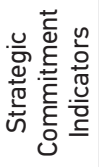 & $\begin{array}{l}\text { Indicator } \\
\text { Description }\end{array}$ & $\begin{array}{c}\text { High } \\
\text { sustainability (2) }\end{array}$ & $\begin{array}{c}\text { Medium } \\
\text { sustainability (1) }\end{array}$ & $\begin{array}{c}\text { Low } \\
\text { sustainability (0) }\end{array}$ & $\begin{array}{l}\text { Quantification of } \\
\text { indicator }\end{array}$ \\
\hline $\mathrm{SC} 1$ & $\begin{array}{l}\text { Public reporting on } \\
\text { sustainability perfor- } \\
\text { mance }\end{array}$ & $\begin{array}{l}\text { Annual sustainability } \\
\text { report published }\end{array}$ & $\begin{array}{l}\text { Sustainability } \\
\text { report published, but } \\
\text { irregularly }\end{array}$ & $\begin{array}{l}\text { Annual sustainability } \\
\text { report not published } \\
\text { yet }\end{array}$ & Fact of publishing \\
\hline SC2 & $\begin{array}{l}\text { Sustainability goals, } \\
\text { SMART objectives de- } \\
\text { termined and specific } \\
\text { programs defined }\end{array}$ & $\begin{array}{l}\text { Sustainability goals, } \\
\text { SMART objectives and } \\
\text { specific programs exist } \\
\text { and are achieved }\end{array}$ & $\begin{array}{l}\text { Sustainability goals, } \\
\text { SMART objectives and } \\
\text { specific programs exist } \\
\text { but are not achieved or } \\
\text { followed }\end{array}$ & $\begin{array}{l}\text { Sustainability goals, } \\
\text { SMART objectives } \\
\text { and specific pro- } \\
\text { grams do not exist }\end{array}$ & $\begin{array}{l}\text { Approved (published) list } \\
\text { of goals and objectives }\end{array}$ \\
\hline SC3 & $\begin{array}{l}\text { Research and } \\
\text { development of pro- } \\
\text { cesses with superior } \\
\text { environmental, social } \\
\text { and economic perfor- } \\
\text { mance }\end{array}$ & $\begin{array}{l}\text { More than one impro- } \\
\text { vement towards more } \\
\text { sustainable products } \\
\text { or services is achieved } \\
\text { per year }\end{array}$ & $\begin{array}{l}\text { One improvement to- } \\
\text { wards more sustainable } \\
\text { products or services is } \\
\text { achieved } \\
\text { per year }\end{array}$ & $\begin{array}{l}\text { No improvement } \\
\text { towards more su- } \\
\text { stainable products or } \\
\text { services is achieved } \\
\text { per year }\end{array}$ & $\begin{array}{l}\text { Financial investment in } \\
R+D \text {; number of initia- } \\
\text { tives for an improved } \\
\text { processes environmen- } \\
\text { tal, social and economic } \\
\text { performance }\end{array}$ \\
\hline SC4 & $\begin{array}{l}\text { Purchasing policies: } \\
\text { Policies and proce- } \\
\text { dures for suppliers' } \\
\text { sustainability evalu- } \\
\text { ation. Promotion of } \\
\text { local suppliers }\end{array}$ & $\begin{array}{l}\text { Policies and procedu- } \\
\text { res related to suppliers' } \\
\text { sustainability exist } \\
\text { and are systematically } \\
\text { applied } \\
\text { Promotion of local } \\
\text { suppliers if quality if } \\
\text { the same or better }\end{array}$ & $\begin{array}{l}\text { Policies and procedures } \\
\text { related to suppliers' } \\
\text { sustainability exist but } \\
\text { are not systematically } \\
\text { applied } \\
\text { Promotion of local } \\
\text { suppliers if quality if the } \\
\text { same and the cost is the } \\
\text { same or less }\end{array}$ & $\begin{array}{l}\text { Policies and pro- } \\
\text { cedures related to } \\
\text { suppliers' sustainabi- } \\
\text { lity do not exist } \\
\text { Absence of pro- } \\
\text { motion of the local } \\
\text { suppliers }\end{array}$ & $\begin{array}{l}\text { Percentage of purchasing } \\
\text { from suppliers compliant } \\
\text { with sustainability criteria } \\
\text { Percentage of purchasing } \\
\text { from local suppliers }\end{array}$ \\
\hline SC5 & $\begin{array}{l}\text { Contribution of the } \\
\text { product or service } \\
\text { to the quality of life, } \\
\text { health and well being } \\
\text { over time Impact on } \\
\text { local communities }\end{array}$ & $\begin{array}{l}\text { The product or service } \\
\text { is necessary for the } \\
\text { improvement of health } \\
\text { and well being over } \\
\text { time } \\
\text { The product, service } \\
\text { or activity positively } \\
\text { impacts local commu- } \\
\text { nities on the middle } \\
\text { and long term }\end{array}$ & $\begin{array}{l}\text { The product or service } \\
\text { improves quality of life, } \\
\text { but is not necessary } \\
\text { for the improvement of } \\
\text { health over time } \\
\text { The product, service } \\
\text { or activity doesn't have } \\
\text { an impact on local } \\
\text { communities on the } \\
\text { middle and long term }\end{array}$ & $\begin{array}{l}\text { The product or servi- } \\
\text { ce does not improve } \\
\text { health, quality of life } \\
\text { and well being over } \\
\text { time } \\
\text { The product, service } \\
\text { or activity negati- } \\
\text { vely impacts local } \\
\text { communities on the } \\
\text { middle and long term }\end{array}$ & $\begin{array}{l}\text { Quantity of treated waste } \\
\text { (Kg),decrease in morbidi- } \\
\text { ty, avoided accidents, etc. } \\
\text { Number of complaints } \\
\text { received from the } \\
\text { community or the clients }\end{array}$ \\
\hline
\end{tabular}




\section{Table 2}

Environmental performance evaluation grid

\begin{tabular}{|c|c|c|c|c|c|}
\hline 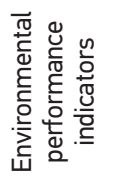 & $\begin{array}{l}\text { Indicator } \\
\text { Description }\end{array}$ & $\begin{array}{c}\text { High } \\
\text { sustainability (2) }\end{array}$ & $\begin{array}{c}\text { Medium } \\
\text { sustainability (1) }\end{array}$ & $\begin{array}{c}\text { Low } \\
\text { sustainability (0) }\end{array}$ & $\begin{array}{l}\text { Quantification } \\
\text { of indicator }\end{array}$ \\
\hline EP1 & $\begin{array}{l}\text { Reduction in material } \\
\text { consumption }\end{array}$ & $\begin{array}{l}\text { At least one initiative is } \\
\text { conducted per year to reduce } \\
\text { material consumption }\end{array}$ & $\begin{array}{l}\text { At least one initiative is } \\
\text { conducted every } 3 \text { ye- } \\
\text { ars to reduce material } \\
\text { consumption }\end{array}$ & $\begin{array}{l}\text { Less than one initiative } \\
\text { is conducted every } 3 \\
\text { years to reduce materi- } \\
\text { al consumption }\end{array}$ & $\begin{array}{l}\text { Weight of materials consumed } \\
\text { (ex: plastic bags) }\end{array}$ \\
\hline EP2 & $\begin{array}{l}\text { Reduction in energy } \\
\text { consumption }\end{array}$ & $\begin{array}{l}\text { Maximal measures are } \\
\text { adopted to reduce energy } \\
\text { consumption (awareness, } \\
\text { installation of heat recovery } \\
\text { system, thermal insulation...) } \\
\text { Maximal use of renewable } \\
\text { sources of energy }\end{array}$ & $\begin{array}{l}\text { Few measures are } \\
\text { adopted to reduce } \\
\text { energy consumption. } \\
\text { Use of renewable ener- } \\
\text { gy if cost-effective }\end{array}$ & $\begin{array}{l}\text { No measures are } \\
\text { adopted to reduce } \\
\text { energy consumpti- } \\
\text { on. No studies were } \\
\text { conducted to see if } \\
\text { renewable energy is } \\
\text { cost-effective }\end{array}$ & $\begin{array}{l}\text { Energy consumption (KWh/ kg } \\
\text { of treated waste). Percentage of } \\
\text { energy consumption from non } \\
\text { renewable resources }\end{array}$ \\
\hline EP4 & $\begin{array}{l}\text { Reduction of air } \\
\text { emissions }\end{array}$ & $\begin{array}{l}\text { Proven absence of pollutant } \\
\text { air emission }\end{array}$ & $\begin{array}{l}\text { Measured, control- } \\
\text { led and treated air } \\
\text { emissions }\end{array}$ & $\begin{array}{l}\text { Non-controlled air } \\
\text { emissions }\end{array}$ & $\begin{array}{l}\text { NO, SO, and other significant air } \\
\text { emissions by type and weight }\end{array}$ \\
\hline EP5 & $\begin{array}{l}\text { Presence of wastewaters } \\
\text { exceeding standards } \\
\text { limits established by re- } \\
\text { gulation (In Lebanon: } \mathrm{pH} \text {, } \\
\mathrm{BOD}, \mathrm{COD}, \mathrm{N}, \mathrm{P}_{2} \mathrm{O}_{5} ; \mathrm{Ni}, \mathrm{Cu} \text {, } \\
\mathrm{Hg} \text {, Total Coliforms, Total } \\
\text { Suspended Solids) }\end{array}$ & $\begin{array}{l}\text { Proven absence of waste- } \\
\text { waters exceeding standards } \\
\text { limits }\end{array}$ & $\begin{array}{l}\text { Measured, controlled } \\
\text { and treated waste- } \\
\text { waters }\end{array}$ & $\begin{array}{l}\text { Presence of non } \\
\text { treated wastewaters } \\
\text { exceeding standards } \\
\text { limits }\end{array}$ & $\begin{array}{l}\text { Wastewaters Volume } \\
\left(\mathrm{L} \text { or } \mathrm{m}^{3}\right) \text { and specifications of } \\
\text { wastewaters before and after } \\
\text { treatment }\end{array}$ \\
\hline EP7 & $\begin{array}{l}\text { Compliance with local } \\
\text { legislation }\end{array}$ & $\begin{array}{l}\text { Compliance with standards } \\
\text { exceeding the local legislation }\end{array}$ & $\begin{array}{l}\text { Compliance with local } \\
\text { legislation }\end{array}$ & $\begin{array}{l}\text { Non compliance with } \\
\text { local legislation }\end{array}$ & $\begin{array}{l}\text { Number and monetary value of } \\
\text { fines, sanctions or complaints }\end{array}$ \\
\hline EP8 & $\begin{array}{l}\text { Conduction of } \\
\text { environmental audits }\end{array}$ & $\begin{array}{l}\text { Conduction of regular envi- } \\
\text { ronmental audits }\end{array}$ & $\begin{array}{l}\text { Conduction of occa- } \\
\text { sional environmental } \\
\text { audits }\end{array}$ & $\begin{array}{l}\text { No conduction of envi- } \\
\text { ronmental audits }\end{array}$ & $\begin{array}{l}\text { Number and results of environ- } \\
\text { mental audits }\end{array}$ \\
\hline EP9 & $\begin{array}{l}\text { Transportation } \\
\text { optimization }\end{array}$ & $\begin{array}{l}\text { Conduction of regular envi- } \\
\text { ronmental maintenance } \\
\text { Transportation is continuo- } \\
\text { usly controlled and opti- } \\
\text { mized; Training and tracking } \\
\text { system allow the verification } \\
\text { of eco-driving practices; } \\
\text { Generalized adoption of } \\
\text { low-emission fuels }\end{array}$ & $\begin{array}{l}\text { Conduction of correcti- } \\
\text { ve maintenance only } \\
\text { Transportation was op- } \\
\text { timized but no updates; } \\
\text { Eco-driving practices } \\
\text { are promoted but not } \\
\text { controlled; Adoption } \\
\text { of low-emission fuels } \\
\text { only if cost-efficient }\end{array}$ & $\begin{array}{l}\text { No maintenance, } \\
\text { Transportation is not } \\
\text { optimized; No pro- } \\
\text { motion of eco-driving } \\
\text { practices } \\
\text { No studies were } \\
\text { conducted to see if } \\
\text { low-emission fuels are } \\
\text { cost-effective }\end{array}$ & $\begin{array}{l}\text { Number of failures, direct and } \\
\text { indirect cost of failures, and num- } \\
\text { ber of workdays lost, Average } \\
\text { vehicle-kilometers driven / kg } \\
\text { treated; Fuel consumption (L)/ } \\
\text { kg of treated waste; Number of } \\
\text { training sessions provided on } \\
\text { eco-driving practices and number } \\
\text { of persons trained; Percentage of } \\
\text { low-emission fuel used }\end{array}$ \\
\hline
\end{tabular}




\section{Table 3}

Social responsibility evaluation grid

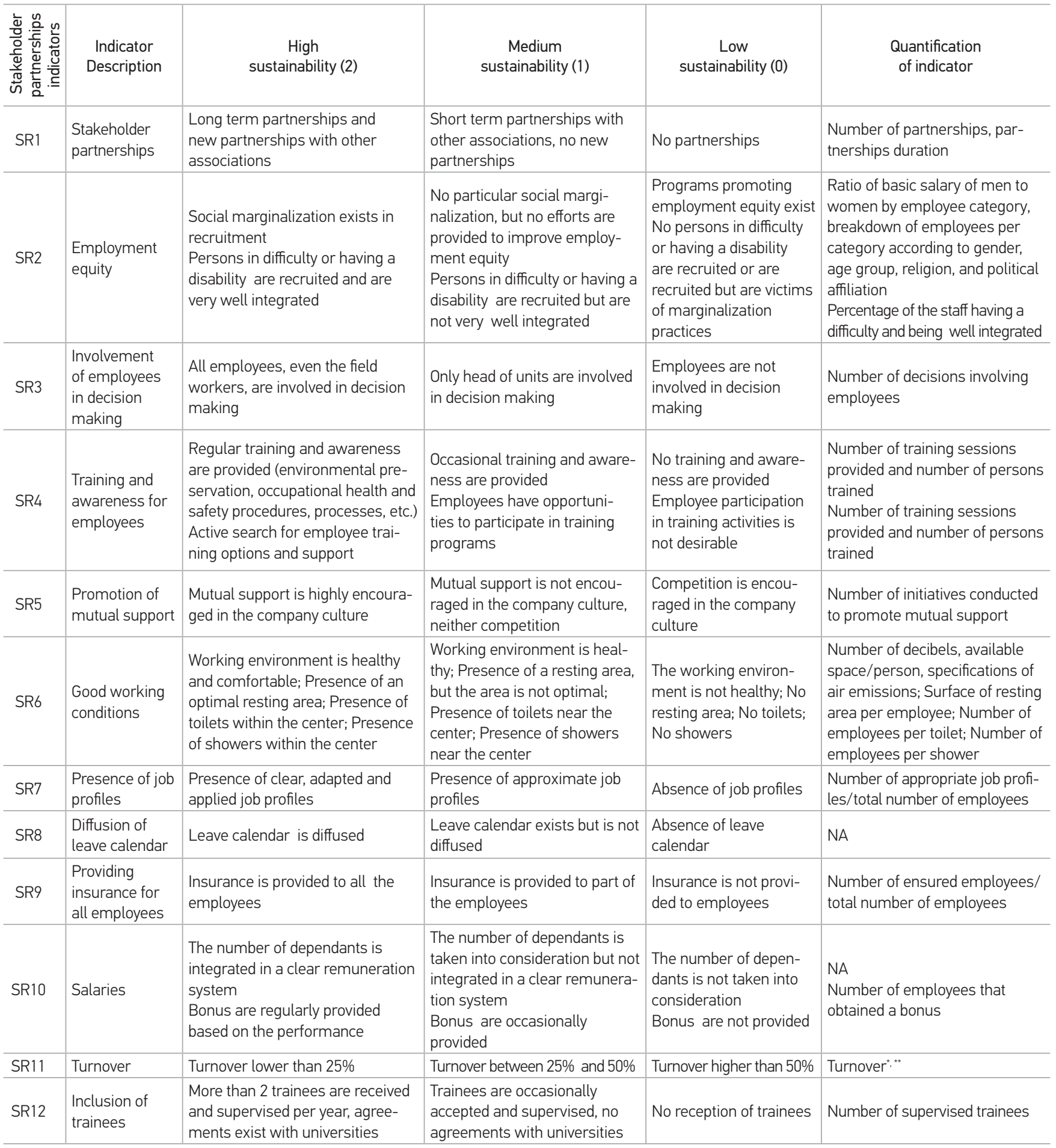

* excluding interim staff and short-term hiring

** Turnover was calculated based on the following formula:
(Number of annual recruitments + number of annual recruitments) $/ 2$ Number of current human ressources at the beginning of the year $* 100$ 
Table 4

Safety performance evaluation

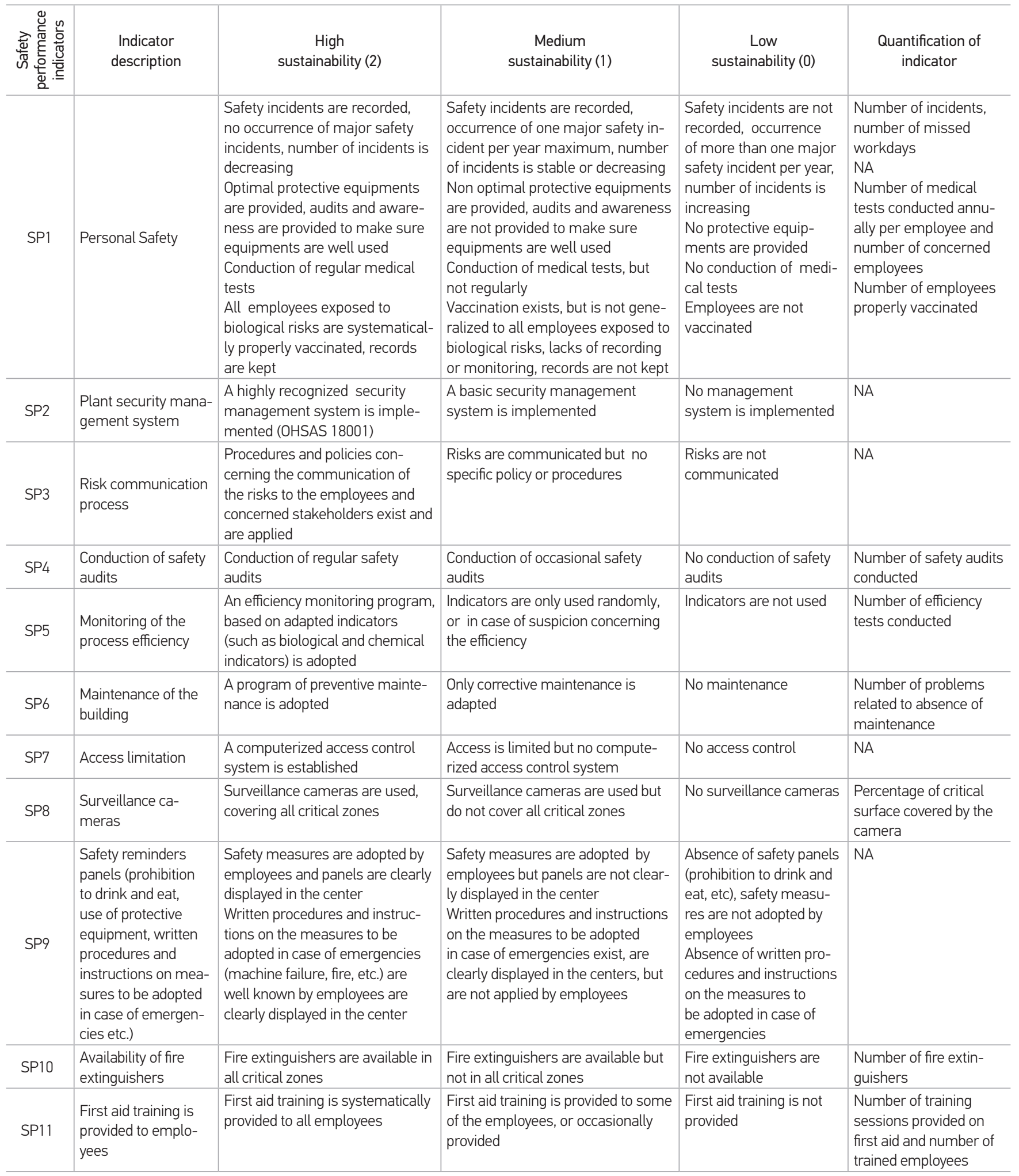




\section{Table 5}

Economic performance evaluation grid

\begin{tabular}{|c|c|c|c|c|c|}
\hline 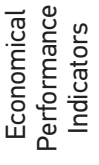 & $\begin{array}{l}\text { Indicator } \\
\text { Description }\end{array}$ & $\begin{array}{c}\text { High } \\
\text { sustainability } \\
\text { (2) }\end{array}$ & $\begin{array}{c}\text { Medium } \\
\text { sustainability (1) }\end{array}$ & $\begin{array}{l}\text { Low } \\
\text { sustainability } \\
\text { (0) }\end{array}$ & $\begin{array}{l}\text { Quantification of } \\
\text { indicator }\end{array}$ \\
\hline EP1 & $\begin{array}{l}\text { Dependence on } \\
\text { operating subsidies }\end{array}$ & $0 \%$ & $0 \%>\mathrm{EP} 1<100 \%$ & $\geq 100 \%$ & $\begin{array}{l}\sum \text { Operating subsidies / Gross Operating } \\
\text { Profit }\end{array}$ \\
\hline EP2 & $\begin{array}{l}\text { Dependence on bank } \\
\text { loans }\end{array}$ & $0 \%$ & $0 \%>\mathrm{EP} 3<100 \%$ & $\geq 100 \%$ & $\begin{array}{l}\text { (Annual installment + short-term financial } \\
\text { costs) / Gross Operating Profit }\end{array}$ \\
\hline EP3 & $\begin{array}{l}\text { General economic } \\
\text { dependence }\end{array}$ & $0 \%$ & $0 \%>E P 3<100 \%$ & $\geq 100 \%$ & $\begin{array}{l}\text { (Annual installment }+ \text { short-term financial } \\
\text { costs }+\Sigma \text { subsidies) / GOP }\end{array}$ \\
\hline EP4 & Return on equity & $>10 \%$ & $5 \%>$ EP $4 \leq 10 \%$ & $\leq 5 \%$ & Net Profit / Equity \\
\hline EP5 & $\begin{array}{l}\text { Capacity of self-finan- } \\
\text { cing for fixed asset } \\
\text { renewal needed }\end{array}$ & $<80 \%$ & $80 \% \geq E P 5<100 \%$ & $\geq 100 \%$ & $\begin{array}{l}\text { (Fixed asset * (depreciation rate }-50 \%)) / \\
\text { Capacity of self-financing }\end{array}$ \\
\hline EP6 & $\begin{array}{l}\text { Investment in new } \\
\text { development activities } \\
\text { or in the improvement } \\
\text { of the same activity }\end{array}$ & $\geq 70 \%$ & $10 \% \geq \mathrm{EP} 6<70 \%$ & $<10 \%$ & $\begin{array}{l}\text { (Raise of fixed assets + investment in new } \\
\text { development activities)/ Net Profit }\end{array}$ \\
\hline EP7 & $\begin{array}{l}\text { Turnover form the } \\
\text { largest customer }\end{array}$ & $<25 \%$ & $25 \% \leq E P 7<50 \%$ & $\geq 50 \%$ & $\begin{array}{l}\text { Total turnover/turnover from the largest } \\
\text { customer }\end{array}$ \\
\hline
\end{tabular}

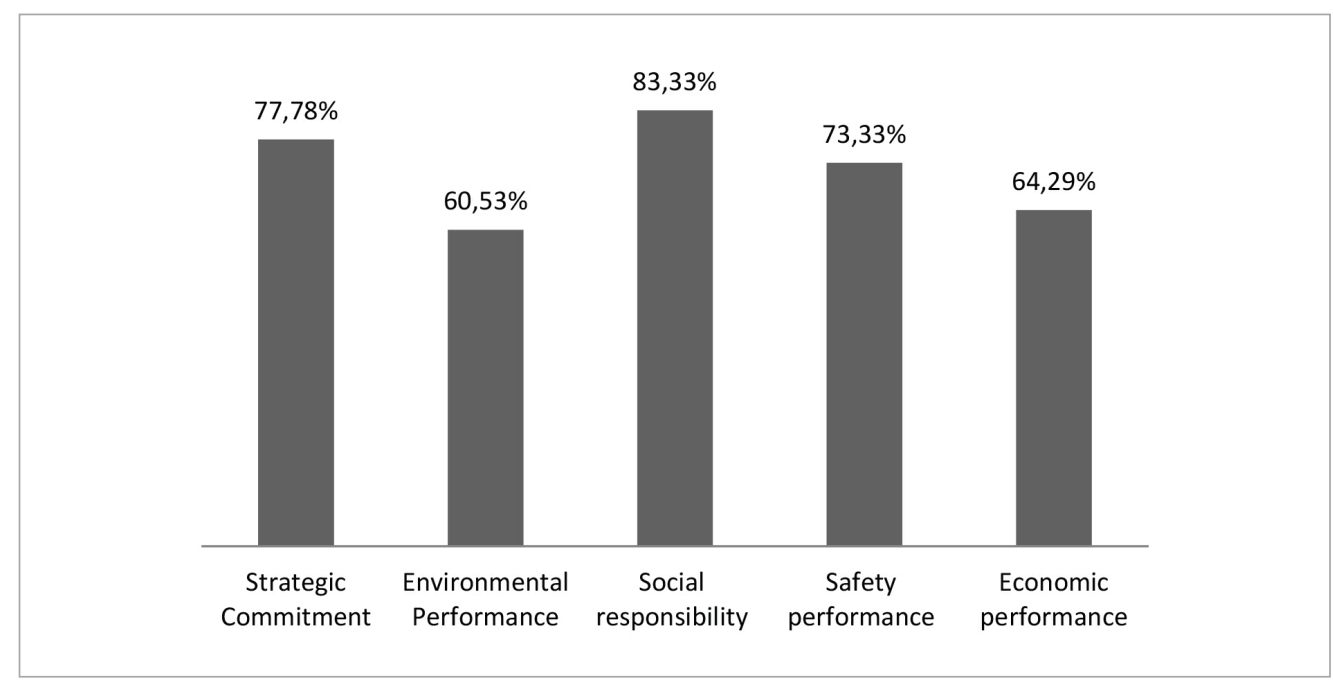

\section{Fig. 1}

Sustainability evaluation results for the Health Care Waste Treatment Sector in Lebanon for the year 2014

Compliance with regulations is very important, however, in some developing countries such as Lebanon where society is disillusioned with weak government an where regulations are not updated, adapted, pertinent, or applicable, some actors such as NGO play a pro-active role, initiating progress and proposing regulations amendments. Thus, measures initiated by the treatment operator to improve cost efficiency or to adapt to the needs and situation on the field can be compliant with international recommendations such 
as WHO guidelines, without being compliant with local regulation.

Dependence on operating subsidies measures the activity dependency on operating subsidies that could be provided by governmental entities for instance. We consider that the sustainability of the action should not depend on these subsidies that could be reduced or withdrawn, notably in developing countries. To measure this dependence, operation subsidies is related to the Gross Operating Profit (GOP) that represents the cash flow generated by the concerned activity. For instance, a dependence on operating subsidies of $50 \%$ means that the cash flow would be reduced by $50 \%$ in the absence of subsidies. When the indicator is equal or higher than $100 \%$, it means that the operator(s) involved in the sector cannot develop the activity or renew fixed assets in the absence of subventions. Dependence on bank loans measures the share of the cash flow that is dedicated to debt repayment. Lower is this dependence; higher is the sustainability of the action. The general economic dependence gathers the dependence on subsidies and the dependence on bank loans. These two indicators are summed up to have a general ideal of dependence on external funding. Return on equity is a profitability indicator measuring the optimization of the financial and material resources. We consider that if the return on equity is lower than the inflation rate $(5 \%$ for instance), the viability of the activity is threatened. Thus, the return on equity should be equal or higher than the inflation rate. Capacity of self-financing for fixed asset renewal measures the financial resources needed for fixed assets renewal at short term, related to the capacity of self-financing. This indicator evaluates the capacity of the operator(s) involved in the sector to renew fixed assets autonomously. We consider that starting form a depreciation rate of $50 \%$, fixed assets should be renewed, and that the equivalent value of the depreciation rate compared to the acceptable depreciation rate of $50 \%$ should be reinvested in fixed assets renewal. Investment in new development activities or in the improvement of the same activity measures the share of profit reinvested in the development or diversification of activities. In fact, the treatment operator should seek to develop its activities. Thus, we consider that to be sustainable, the operator should invest more than the majority if its profits in activity (quality, technology, capacity) development. Turnover from the largest customer measures the dependence on the largest customer. Lower is this indicator, more the activity is sustainable.

The evolution of the level of sustainability rates (reduction of low sustainably occurrence and increasing of the number of indicators rated as highly sustainable) of each indicator each year allows monitoring positive changes over time. The progress of these results among years allows evaluating the efficiency of the measures adopted. The progression of low and medium sustainability rates towards high sustainability rates over time reflects the speed of progress in terms of strategic commitment, environmental performance, social responsibility, safety performance and economic performance. This speed will depend on the contextual capacity of implementing actions toward sustainability (financial capacities, technical advancement etc.).

\section{Conclusion}

Sustainable indicators constitute a tool to be used in promoting mainstream and tangential consideration of sustainable development. The measurement and monitoring of sustainability performance can be considered as a tool to be integrated in the quality loop within management system.

The proposed sustainability system brings to light sustainability parameters to be taken into consideration in the Health Care Waste Treatment sector, and helps in establishing measures and options to be adopted for the improvement of sustainability applied to this sector in a developing country, and to follow the improvement among time. Rating the level of sustainability for each indicator allows identifying priority areas of improvement. Based on his identification, Key Performance Indicators are selected, allowing monitoring the progress through proposed quantification methods. The qualitative nature of some indicators and data, that could constitute a limit to the objectivity of the performance evaluation, is here counterbalanced by the proposed quantification of indicators. The evolution of the level of sustainability rates (reduction of low sustainably rates indicators and increasing of 
the number of indicators rated as highly sustainable) of each indicator each year allows monitoring positive changes over time in terms of strategic commitment, environmental performance, social responsibility, safety performance and economic performance. The system can be adapted also to the priorities and context, through utilization of weighing factors. The

\section{References}

Azapagic, A.; Perdan, S. (2000) Indicators of Sustainable Development for Industry: A General Framework, Process Safety and Environmental Protection. 07/2000; 78(4):243-261. DOI: 10.1205/095758200530763.

Cobb, C., Schuster, D., Beloff, B., and Tanzil, D., (2007) Benchmarking sustainability, Chem. Eng. Prog., 103 ( 6): 38 - 42.

Dursun, M., Ertugrul Karsak E., and Karadayi, M.A. (2011). Assessment of health-care waste treatment alternatives using fuzzy multi-criteria decision making approaches. Resour Conserv Recy, Vol. 57, 98-107.

Global Reporting Initiative (2000-2006) Sustainability Reporting guidelines

Yazdi, S. A general framework for sustainability performance assessment of steel industry (2014) International Journal of Sustainable Human Development, 2(1), 8-17. Ó 2014. First published by Eduserv Group Publishing Division, UK, 2014 8. Environmental Research, Engineering and Management, 2009. No. 2(48), P. 42-50.

Fortună, M.E; Simion I.M, Gavrilescu, M. (2011) Indicators for sustainability in industrial systems. Case Study: paper manufacturing, Paper presented at the International Conference of Applied Sciences, Chemistry and Chemical Engineering CISA 2011, 28-30 April 2011, Bacău, Romania 2011, 12 (4), pp. 363 - 372. ISSN 1582-540X

Harmsen, J. Powell, J., (2010), Sustainable Development in the Process Industries: Cases and Impact. 2010. ISBN: 9780-470-18779-1

Raizer Neto, E.; Mariotte, M.T; Hinz R.T.P. (2006). Indicators to measure sustainability of an industrial manufacturing,. 2006, pp 111-122

Sikdar, S. K., (2007), Sustainability perspective and chemistry - based technologies. Ind. Eng. Chem. Res. , 46 ( 14 ): $4727-4733$

Staniškis, J; Arbačiauskas, V. (2009) Sustainability Performance Indicators for Industrial Enterprise Management, En- proposed evaluation system will contribute to an improvement in the long run societal resource economy, notably through reduction of environmental degradation costs, the reduction of the healthcare bill, the creation of green jobs, and the development of a green economic sector.

vironmental Research, Engineering and Management, 2009. No. 2(48), P. 42-50. ISSN 1392-1649.

Maamari, O; Brandam, C.; Lteif, R. ; Salameh, D. (2015a). The creation and monitoring of a network for solid healthcare waste management. Int. J. Environment and Waste Management, Vol. 15, No. 2, 2015.

Maamari, O; Brandam, C.; Lteif, R. ; Salameh, D. (2015b). Health Care Waste generation rates and patterns: The case of Lebanon. Waste Management, 2015. No. 43, P. 550-554.

United States Environmental Protection Agency (EPA) (2012) A Framework for Sustainability Indicators at EPA EPA/600/R/12/687; www.epa.gov/ord

Van Passel S., Van Huylenbroeck G., Lauwers L., Mathijs E. (2009) Sustainable value assessment of farms using frontier efficiency benchmarks. J Environ Manage. 2009 Jul;90(10):3057-69. doi: 10.1016/j.jenvman.2009.04.009. Epub 2009 Jun 23.

Warhurst A., (2002), Sustainability Indicators and Sustainability Performance Management. Mining, minerals, and Sustainable Development. No 43.

Wilson, J., Tyedmers, P., and R. Pelot (2007) Contrasting and comparing sustainable development indicator metrics. Ecol. Indicators , 7 ( 2 ): 299 - 314

WHO, Safe management of wastes from health-care activities, 2nd Edition, (2013)/

World Commission on Environment and Development (WCED) (1987), Our Common Future, ('The Brundtland Report') Oxford University Press: 8

Zahm F., Viaux P., Vilain L., Giradin P., Mouchet C. (2004) The IDEA method (Farm Sustainability Indicators): a diagnostic assessment method to make the transition from the concept of sustainability to its assessment using indicators; in proceedings of PEER Conference; 17th to 18th November 2004; Helsinki, Finland; submitted in January 2005 to Sustainable Development (Wiley Interscience) with the following title "Assessing farm sustainability with the Farm Sustainability Indicators method 


\section{Darnios plètros rodikliai sveikatos priežiūros atliekų tvarkymo pramonèje}

\section{Olivia Maamari}

Beiruto Šventojo Juozapo universitetas, Chemijos katedra, Beirutas, Libanas

"arcenciel", aplinkos apsaugos programa, Beirutas, Libanas

Aplinkos tyrimu padalinys, Funkcinès genomikos ir matematikos centras (UR-EGFEM), Tulūza, Prancuzija

\section{Jounaid Maurice}

"arcenciel", aplinkos apsaugos programa, Beirutas, Libanas

\section{Cedric Brandam}

Nacionalinė chemijos inžinerijos, technologijų ir menų mokykla, Tulūza, Prancuzija

Cheminès inžinerijos laboratorija, Tulūza, Prancuzija

\section{Roger Lteif}

Beiruto Šventojo Juozapo universitetas, Chemijos katedra, Beirutas, Libanas

Beiruto Šventojo Juozapo universitetas, Sveikatos technologiju skyrius, Beirutas, Libanas

Aplinkos tyrimu padalinys, Funkcinès genomikos ir matematikos centras (UR-EGFEM), Tulūza, Prancuzija

\section{Dominique Salameh}

Beiruto Šventojo Juozapo universitetas, Chemijos katedra, Beirutas, Libanas

Aplinkos tyrimu padalinys, Funkcinės genomikos ir matematikos centras (UR-EGFEM), Tulūza, Prancuzija

Darnus vystymasis vis labiau vertinamas kaip pagrindinis pasaulio vystymosi parametras ir varomoji strategija. Šiandien daugybè organizaciju sukuria savo veiklos rodiklius, todèl kalbant apie darnią veiklą, nèra standartizuoto veiklos rodikliu rinkinio. Tai ypač tinka kalbant apie besivystančias šalis, kuriose darnumo sąvoka dar nèra daug paplitusi, ir kuriose ekonominiai sunkumai ir apribojimai daugiausiai j̇akoja nepakankamą aplinkos ir socialinès erdvės jivertinimą, todèl ten reikalinga sukurti specialiai pritaikytu rodiklių. Ypač sveikatos priežiūros atliekų tvarkymo sektoriuje trūksta darnumo vertinimo rodiklių. Šis sektorius užtikrina sveikatos priežiūros centruose esančių pavojingu sveikatos priežiūros atliekų apdorojimą prieš ju pašalinimą (ligoninès, klinikos ir kt.). Vertinimo sistema skirta kontroliuoti šio sektoriaus darnaus augimo tempą. Šio tyrimo tikslas yra pasiūlyti darnumo vertinimo sistemą, pritaikytą besivystančiu šaliu poreikiams ir padéčiai, pagristą prasmingais, praktiniais, lengvai išmatuojamais ir taikytinais infektuotu sveikatos priežiūros atlieku (USPA) tvarkymo rodikliais.

Raktiniai žodžiai: sveikatos priežiūros infektuotų atliekų tvarkymo pramonè, darnios plètros rodikliai, veiksmingumas. 